\title{
Relative importance of the different negative effects of the toxic haptophyte Prymnesium parvum on Rhodomonas salina and Brachionus plicatilis
}

\author{
Aldo Barreiro ${ }^{1, *}$, Cástor Guisande ${ }^{1}$, Isabel Maneiro ${ }^{1}$, Trinh Phuong Lien ${ }^{2}$, \\ Catherine Legrand ${ }^{3}$, Timo Tamminen ${ }^{4}$, Sirpa Lehtinen ${ }^{4}{ }_{\text {Pauliina Uronen }}^{5}$, Edna Granéli ${ }^{3}$ \\ ${ }^{1}$ Facultad de Ciencias, Universidad de Vigo, Lagoas-Marcosende 36200 Vigo, Spain \\ ${ }^{2}$ Friedrich-Schiller-Universität Jena, Institut für Ernährungwissenchaften, Dornburger Strasse 25, 07743 Jena, Germany \\ ${ }^{3}$ Marine Sciences Department, University of Kalmar, 39182 Kalmar, Sweden \\ ${ }^{4}$ Finnish Environment Institute (SYKE), Research Department/Baltic Sea Protection Research, Plankton Ecology Team, \\ 00251 Helsinki, Finland \\ ${ }^{5}$ Tvärminne Zoological Station, 10900 Hanko, Finland
}

\begin{abstract}
The aim of this study was to determine the relative importance of the different processes/mechanisms by which the toxic haptophyte Prymnesium parvum, cultured under different nutrient conditions, affects non-toxic phytoplankton competitors and microzooplankton grazers. P. parvum was cultured under steady-state growth in different nutrient conditions: nitrogen depleted $(-\mathrm{N})$, phosphorus depleted $(-\mathrm{P})$ and balanced nitrogen and phosphorus $(+\mathrm{NP})$. Cells from each nutrient condition and culture cell-free filtrates, alone and combined with non-toxic prey (Rhodomonas salina), were used as food for the rotifer Brachionus plicatilis. An additional experiment was carried out to test the effect of $P$. parvum cells and culture cell-free filtrate on $R$. salina. The highest haemolytic activity values were achieved by $-\mathrm{P}$ P. parvum cultures, followed by $-\mathrm{N}$. However, the negative effect of $P$. parvum on $R$. salina and rotifers did not correlate with haemolytic activity but with the number of $P$. parvum cells. -N-cultured P. parvum were the most toxic for both $R$. salina and rotifers, followed by + NP. Therefore, haemolytic activity is not a good indicator of the total potential toxicity of $P$. parvum. The growth rate of $R$. salina was negatively affected by cell-free filtrates but the effect of $P$. parvum predation was greater. Rotifers fed on both toxic and non-toxic algae, indicating that they did not select against the toxic alga. The $P$. parvum cell-free filtrate had an effect on $B$. plicatilis, although this was weak. B. plicatilis was also indirectly affected by $P$. parvum due to the negative effects of the toxic alga on their prey $(R$. salina). However, the greatest negative effect of $P$. parvum on the rotifers was due to ingestion of the toxic cells. Therefore, the phytoplankton competitor $R$. salina is more affected by $P$. parvum predation and the grazer B. plicatilis is more affected by ingestion of the toxic cells, the effects of excreted compounds being secondary.
\end{abstract}

KEY WORDS: Haptophytes · Prymnesium parvum • Nutrient limitation · Toxicity · Haemolytic activity $\cdot$ Allelopathy $\cdot$ Rotifers $\cdot$ Zooplankton $\cdot$ Phytoplankton

\section{INTRODUCTION}

Blooms of toxic haptophytes are common phenomena in some areas (Scandinavia, Israel, Australia, North America) where their toxic effects are well documented (Shilo 1967, Edvarsen \& Paasche 1998). Prymnesium parvum belongs to this group and produces exotoxins (prymnesins) with cytotoxic, neurotoxic and ichthyotoxic activity (Shilo 1967, Igarashi et al. 1998).

Most of the studies carried out with Prymnesium parvum have been concerned with the effects of abiotic factors on its toxicity. Light, salinity and tempera- 
ture were not found to affect toxicity (Larsen \& Bryant 1998), but toxin production increases when $P$. parvum is grown under both nitrogen and phosphorus limitation (Johansson \& Granéli 1999a,b). In the field, recurrent blooms of $P$. parvum with high toxicity associated with high N:P ratios have also been observed (Aure \& Rey 1992, Lindholm 1998).

Toxicity is significantly reduced when bacteria are supplied to Prymnesium parvum cultured under nutrient limitation (Nygaard \& Tobiesen 1993, Legrand et al. 2001). However, Skovgaard et al. (2003) found no difference in the feeding rate of $P$. parvum on Rhodomonas baltica when $P$. parvum was grown under nutrient deficient conditions ( $\mathrm{N}$ and $\mathrm{P}$ ). But despite the different culture conditions used in these experiments, all treatments had some degree of nutrient limitation, as shown by intracellular ratios.

Some studies have hypothesised that toxin production in haptophytes like Prymnesium parvum and Chrysochromulina polylepis is not directly coupled to nutrient limitation, but is a function of the physiological status of the cell (Johansson \& Granéli 1999a,b, Legrand et al. 2001). However, Stolte et al. (2002) showed that toxins were produced in both Alexandrium tamarense and $P$. parvum in proportion to chlorophyll when the algae were grown in semicontinuous cultures, and they did not accumulate, as is seen in the stationary phase of batch cultures.

Studies of the allelopathic effect of Prymnesium parvum on non-toxic phytoplankton species have shown that $P$. parvum can inhibit the growth of these potential competitors by the excretion of allelochemicals into the water (Fistarol et al. 2003, Granéli \& Johansson 2003a,b, Skovgaard \& Hansen 2003). Other studies have shown that $P$. parvum can also ingest phytoplankton species (Martín-Cereceda et al. 2003, Skovgaard \& Hansen 2003). Tillmann (2003) found that $P$. parvum can kill potential predators, such as the dinoflagellate Oxyrrhis marina, with allelochemicals and thereafter eat them.

Some micro- and mesozooplankton are negatively affected in the presence of Prymnesium parvum. Nejstgaard \& Solberg (1996) demonstrated sublethal effects on the copepod Acartia clausi without ingestion of toxic cells. Koski et al. (1999) reported negative effects on reproduction and survival of the copepod Eurytemora affinis due to the ingestion of toxic Prymnesium patelliferum cells; however, mortality of the copepods was more closely related to $P$. patelliferum concentration in the medium rather than cell ingestion, which suggests a role for excreted toxins. Rosetta \& McManus (2003) detected high mortality in ciliates fed with $P$. parvum, and sublethal effects have been observed for the ciliate Euplotes affinis in the presence of $P$. parvum (Granéli \& Johansson 2003b).
Therefore, it is clear that Prymnesium parvum can produce toxic effects on plankton species via different processes/mechanisms, which may play an important role in structuring plankton communities: cell lysis by toxins and phagocytic activity towards bacteria and phytoplankton; and negative effects on zooplankton due to excreted toxins, ingestion of toxic cells and competition with zooplankton grazers for prey. The relative importance of these different toxic effects produced by $P$. parvum has never been studied.

The aim of this study was to determine the relative importance of the different negative effects of Prymnesium parvum, cultured under different nutrient conditions, on the population growth rates of a non-toxic phytoplankton species (Rhodomonas salina) and of the rotifer Brachionus plicatilis.

\section{MATERIALS AND METHODS}

Algal cultures. Prymnesium parvum (strain KAC39, Kalmar Algal Collection, University of Kalmar, 7 to $9 \mu \mathrm{m}$ equivalent spherical diameter) was cultured in f/20 medium (Guillard \& Ryther 1962) modified to $\mathrm{N}=$ $58 \mu \mathrm{M}, \mathrm{P}=3.63 \mu \mathrm{M}$. Rhodomonas salina (6 to $9 \mu \mathrm{m}$ equivalent spherical diameter), obtained from the Tvärminne Zoological Station culture collection, Finland (Hällfors \& Hällfors 1992), was grown under the same conditions as $P$. parvum. The algal cultures were grown under a 14:10 h light:dark cycle at 16 ( $P$. parvum) and $18^{\circ} \mathrm{C}(R$. salina). Autoclaved and filtered $(0.22 \mu \mathrm{m}$ glass fibre filter) seawater from the Gulf of Finland (salinity $6 \mathrm{psu}$ ) was used to prepare the culture media.

Prymnesium parvum cultures were first grown as batch cultures until high biomass was reached, but the cells were still in exponential growth. Thereafter, $20 \%$ of the volume was replaced daily with fresh media, which produced steady-state growth conditions (Johansson \& Granéli 1999a).

After steady-state growth was initially established for the Prymnesium parvum cultures, 3 different nutrient treatments were started in triplicate: nitrogen deficiency $(-\mathrm{N})$, phosphate deficiency $(-\mathrm{P})$ and balanced nitrogen and phosphate conditions (+NP). The concentrations and ratios of nutrients in the treatments were: $-\mathrm{P}\left(\mathrm{N}: \mathrm{P}=80: 1,80 \mu \mathrm{M} \mathrm{NO}^{3-}, 1 \mu \mathrm{M} \mathrm{PO}\right),-\mathrm{N}(\mathrm{N}: \mathrm{P}=4: 1$, $16 \mu \mathrm{M} \mathrm{NO}^{3-}, 4 \mu \mathrm{M} \mathrm{PO}$ ) and +NP (both nutrients corresponding to f/20 medium [Guillard \& Ryther 1962] modified to $\mathrm{N}=58 \mu \mathrm{M}, \mathrm{P}=3.63 \mu \mathrm{M})$. Experiments were run during the last third of steady-state growth. Cell abundances were measured daily with an ELZONE electronic particle counter (Particle Data). Nutrient analyses were performed daily in order to ensure that cells were N- or P-depleted (P. Uronen et al. unpubl. data). The haemolytic activity of Prymne- 
sium parvum cells and cell-free filtrate was measured daily in the cultures to determine cell toxicity.

Rotifer cultures. The SINTEF-strain (L-strain) of Brachionus plicatilis (Olsen et al. 1993) was fed with Rhodomonas salina and kept in culture for a few months before the experiments. Light and temperature conditions were the same as for $R$. salina cultures.

Experimental design. Effect of Prymnesium parvum on Rhodomonas salina growth: To test the effect of dissolved toxins on $R$. salina growth rate, $P$. parvum cultures were filtered through GF/F filters and the cellfree filtrate was added to $10 \times 10^{3}$ cells ml ${ }^{-1} R$. salina suspensions at different percentages: $10,25,50$ and $90 \%$. To check the combined effect of phagotrophy and dissolved toxins (allelochemicals) on $R$. salina growth rate, different $P$. parvum concentrations $(2,10$, 25 and $50 \times 10^{3}$ cells ml ${ }^{-1}$ final concentration) were added to $10 \times 10^{3}$ cells ml ${ }^{-1} R$. salina suspensions. Experimental cell suspensions were kept in $25 \mathrm{ml}$ beakers, with 7 replicates for each $P$. parvum nutrient condition $(-\mathrm{P},-\mathrm{N}$, and $+\mathrm{NP})$. The experiments were carried out over $24 \mathrm{~h}\left(10: 14 \mathrm{~h}\right.$ light:dark cycle, $\left.18^{\circ} \mathrm{C}\right)$. Samples were taken at the beginning of the experiment and after $24 \mathrm{~h}$, fixed with $4 \%$ paraformaldehyde and counted using flow cytometry.

Rotifer mortality and grazing experiments: For each Prymnesium parvum culture $(-\mathrm{P},-\mathrm{N}$ and $+\mathrm{NP})$, we ran 5 different treatments with the rotifers: (1) rotifers and $P$. parvum alone (Pry); (2) rotifers with P. parvum and Rhodomonas salina $(\text { Pry }+R h o)_{i}$ (3) rotifers with P. parvum cell-free filtrate and $R$. salina $(R h o+F) ;(4)$ rotifers with filtered seawater in starvation conditions; and (5) rotifers with $R$. salina alone (Rho).

The final densities of Prymnesium parvum and Rhodomonas salina were 2, 50 and $100 \times 10^{3}$ cells ml $^{-1}$ for Pry and Rho treatments, and 2 and $50 \times 10^{3}$ cells $\mathrm{ml}^{-1}$ in Pry + Rho and Rho $+\mathrm{F}$ treatments. $R$. salina: $P$. parvum cell ratios were always 1:1. The experiments were carried out with 15 replicates of 15 rotifers in $25 \mathrm{ml}$ beakers. Rotifers were counted daily and transferred to new cell suspensions. The experimental conditions were 10:14 h light:dark cycle and $18 \pm 1^{\circ} \mathrm{C}$. In order to run all nutrient conditions and treatments simultaneously, we stopped the experiments when the first treatment lost the entire rotifer population $(5 \mathrm{~d}$, Treatment Pry, $-\mathrm{N}$ ).

Growth and mortality of the rotifer population were estimated from the daily population counts. Growth rates were calculated according to $N=N_{0} \mathrm{e}^{r t}$, where $N$ is the final rotifer density, $N_{0}$ is the initial rotifer density, $r$ is the growth rate and $t$ is time.

The ingestion rates were estimated on the second day of the experiment. For this purpose we used 10 beakers without grazers (controls) and the 15 replicate beakers containing rotifers per treatment. Samples were fixed initially and after $24 \mathrm{~h}$ with $4 \%$ paraformaldehyde. Cell numbers were counted using a flow cytometer. Cell abundances were converted to carbon estimates using $32 \mathrm{pg} \mathrm{cell}^{-1}$ for Prymnesium parvum (Legrand et al. 2001) and $45 \mathrm{pg} \mathrm{cell}^{-1}$ for Rhodomonas salina (Nejstgaard \& Solberg 1996). Ingestion rates were calculated according to Frost's (1972) equations and negative values were considered as zero.

Analytical procedures. Haemolytic activity of Prymnesium parvum: Cells and cell-free filtrates were collected after filtration of $10 \mathrm{ml}$ cultures onto GF/C glass microfibre filters. Toxins in the cells were extracted with $2 \mathrm{ml}$ methanol (Igarashi et al. 1998). Extracellular toxicity was measured using a haemolytic test on the cell-free filtrates. The haemolytic activity of cell methanol extracts and cell-free filtrates on horse blood cells was measured in duplicate (Igarashi et al. 1998). Horse blood was washed and resuspended in isotonic phosphate buffer (IPB) (Fistarol et al. 2003). Cell methanol extract or cell-free filtrate was mixed with IPB at different ratios ( 0 to $100 \%$ ) and $50 \mu \mathrm{l}$ was added to $200 \mu \mathrm{l}$ of horse blood cell suspension in microplates (Falcon, 96 wells). A standard curve was made with saponin (Sn). After $1 \mathrm{~d}$ dark incubation at room temperature, the microplates were centrifuged $(3000 \mathrm{rpm}[32 \times g] 5$ min, Beckman AllegraTM centrifuge), and the supernatant $(110 \mu \mathrm{l})$ was transferred to new microplates (black Costar ${ }^{\circledR}, 96$ wells). The absorbance at $540 \mathrm{~nm}$ was read on a Fluostar 403 microplate reader. The results were expressed as $\mu \mathrm{g}$ Sn equivalent (Sneq) $\mathrm{ml}^{-1} P$. parvum culture.

Phytoplankton enumeration: Phytoplankton cells were counted using a flow cytometer (FACSCalibur, Beckton-Dickson) which can distinguish between Prymnesium parvum and Rhodomonas salina. The ability to distinguish between the 2 similarly sized species is mainly due to detection by the FL-2 H fluorescence detector (yellow-orange fluorescence, 560 to $600 \mathrm{~nm}$ ) and, to a lesser extent, by the FL-3 H detector (red fluorescence, 640 to $700 \mathrm{~nm}$ ).

Statistical analyses. All statistical analyses were performed with SPSS 11.0 (2003: SPSS Headquarters).

\section{RESULTS}

\section{Prymnesium parvum cultures}

During steady-state growth, Prymnesium parvum cell densities were (mean \pm SD) $368000 \pm 21000,310000 \pm$ 13000 and $148000 \pm 15000$ for $\mathrm{NP},-\mathrm{P}$ and $-\mathrm{N}$ treatments, respectively. The cell densities between each nutrient condition during steady-state conditions were significantly different (analysis of covariance, [ANCOVA] with time as covariate, $F_{1,134}=89.1, \mathrm{p}<0.001$ ). 
The highest haemolytic activity was measured in Prymnesium parvum cells grown in $-\mathrm{P}$ cultures and the lowest was measured in +NP (Fig. 1) Haemolytic activity values were significantly different among nutrient conditions during the whole experiment (ANCOVA with time as covariate, $F_{1,42}=19.1, \mathrm{p}<$ 0.001). No haemolytic activity was detected in any of the $P$. parvum cell-free filtrates, although the small volumes analysed (5 to $100 \mu \mathrm{l}$ ) reduced the sensitivity of the assay. Thus, the presence of low levels of haemolytic substances cannot be excluded.

\section{Effect of Prymnesium parvum on the growth rate of Rhodomonas salina}

Both treatment with Prymnesium parvum cells and cell-free filtrates negatively affected the growth rate of Rhodomonas salina in all nutrient conditions (Figs. 2 \& 3) An ANCOVA, taking the volume of the P. parvum cell-free filtrate as covariate (log-transformed) and the different nutrient conditions as factor, showed that the $R$. salina growth rate was significantly reduced as the volume of the cell-free filtrate added increased $\left(F_{1,74}=57.5, \mathrm{p}<0.001\right.$, Fig. 2$)$, and there were significant differences among the nutrient conditions $\left(F_{2,74}=9.1 \mathrm{p}<0.001\right)$. As no haemolytic activity was detected in the cell-free filtrate, this might indicate that there are toxic compounds not detected by the haemolytic test, which negatively affect the growth rate of $R$. salina.

Although there is a negative relationship between Rhodomonas salina growth rate and both Prymnesium

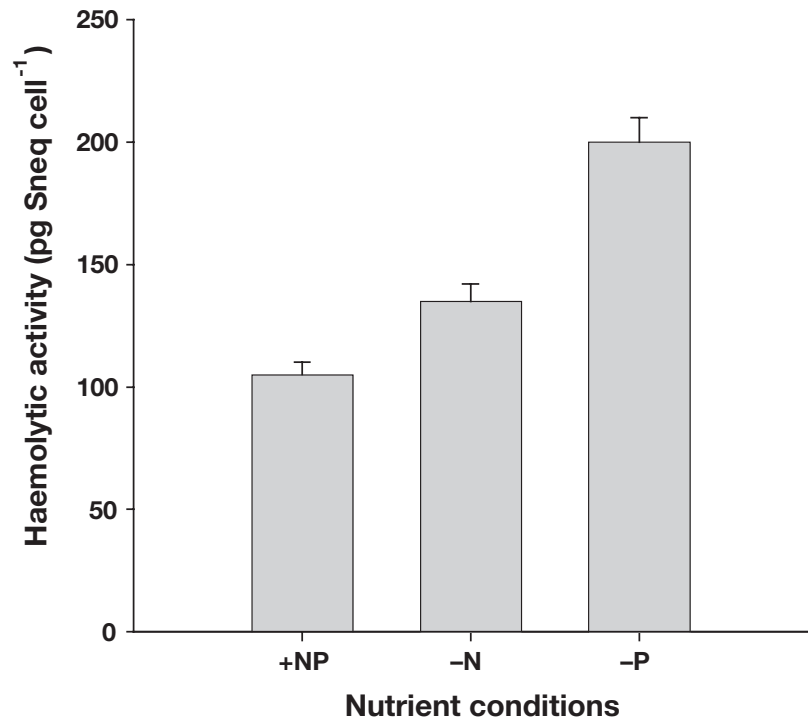

Fig. 1. Prymnesium parvum. Haemolytic activity in the $-\mathrm{P},-\mathrm{N}$ and $+\mathrm{NP}$ cultures during Days 16 to 26 . Values are mean $\pm \mathrm{SE}$. Sneq: saponin equivalent

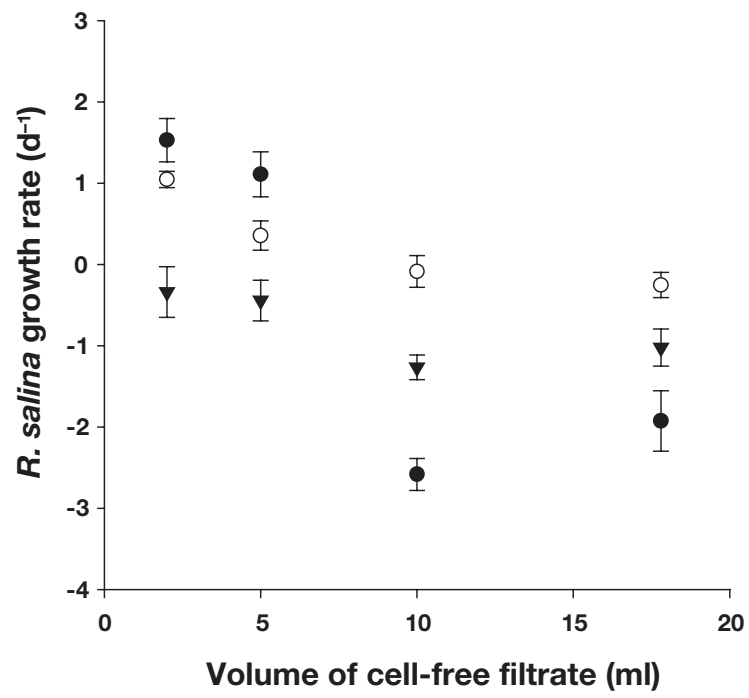

Fig. 2. Rhodomonas salina. Relationship between growth rate (mean $\pm \mathrm{SE}, \mathrm{n}=7$ ) and the volume of cell-free filtrate from Prymnesium parvum cultured under the different nutrient conditions +NP $(\bullet),-\mathrm{P}(\mathrm{O})$ and $-\mathrm{N}(\mathbf{\nabla})$
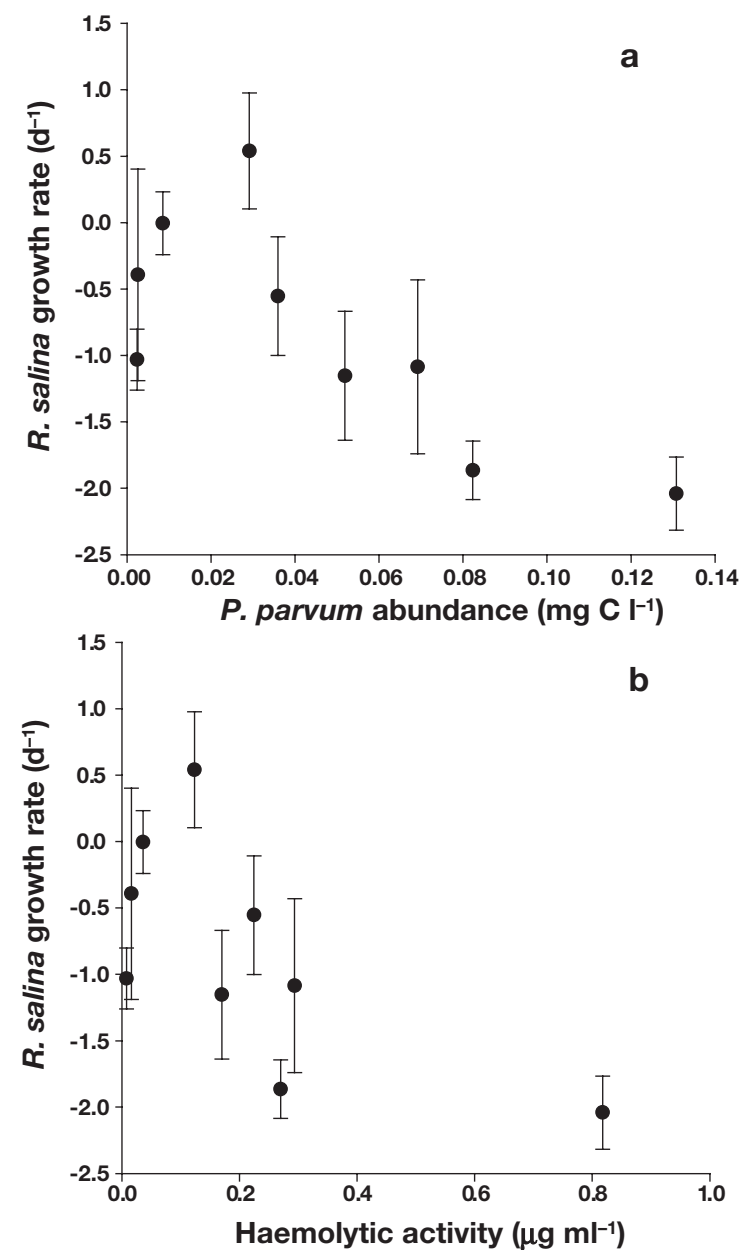

Fig. 3. Rhodomonas salina. Relationship between growth rate (mean $\pm \mathrm{SE}, \mathrm{n}=7$ ) and (a) Prymnesium parvum abundance, (b) haemolytic activity 
parvum abundance (Fig. 3a) and haemolytic activity (Fig. 3b), a stepwise multiple regression showed that only $P$. parvum cell abundance (log-transformed) was significantly related to $R$. salina growth rate $\left(F_{1,179}=\right.$ 83.7, $\mathrm{r}^{2}=0.32, \mathrm{p}<0.001$ ), indicating that the effect of $P$. parvum predation on $R$. salina growth rate was greater than the haemolytic effect.

\section{Ingestion rates}

Rotifers fed on both toxic and non-toxic algae (Fig. 4). There were no significant differences between the rates of Rhodomonas salina and Prymnesium parvum ingestion in the mixed cultures (ANCOVA with each algal concentration as covariate, $F_{1,174}=$ $0.51, \mathrm{p}=0.47$ ), indicating that the rotifers did not select against the toxic alga. When offered alone, $P$. parvum was ingested at higher rates than when offered mixed with $R$. salina. Rates of $R$. salina ingestion were lower than those of $P$. parvum in the treatments where both algae were offered alone (Pry and Rho). However, $R$. salina seemed to be ingested at a higher rate in the $R h o+$ F treatments (except $-\mathrm{P}$ ) than in Rho.

\section{Effect of Prymnesium parvum on the growth rate of rotifers}

For $-\mathrm{P},-\mathrm{N}$ and $+\mathrm{NP}$, a stepwise multiple regression showed that there was a clear relationship between the growth rate of rotifers $\left(G\right.$, in no. $\left.\mathrm{d}^{-1}\right)$ and, Rhodomonas salina $(R)$ and Prymnesium parvum $(P)$ abundances (both in $\mathrm{mg} \mathrm{C} \mathrm{ml}^{-1}$ ); the volume of cell-free

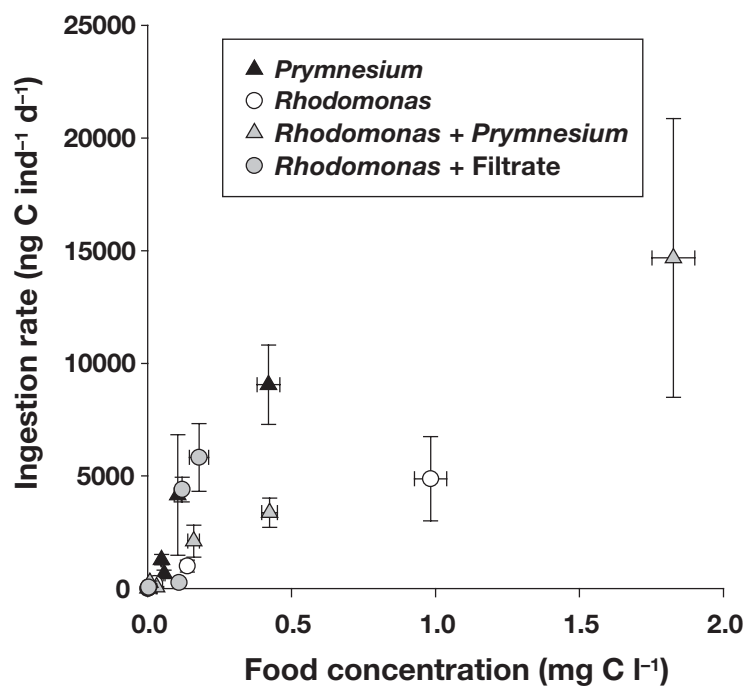

Fig. 4. Brachionus plicatilis. Relationships between total food concentration and total ingestion rate $($ mean $\pm \mathrm{SE}, \mathrm{n}=15)$ filtrate ( $V$, in $\mathrm{ml}$ ) had a significant negative effect in $-\mathrm{N}$ and $+\mathrm{NP}$ treatments but not in the $-\mathrm{P}$ treatment:

$$
\begin{gathered}
-\mathrm{P}: G=-0.04+0.51 \log (R+1)-0.23 \log (P+1) \\
F_{2,161}=299, \mathrm{r}^{2}=0.79, \mathrm{p}<0.001 \\
-\mathrm{N}: G=-0.09+0.78 \log (R+1)- \\
1.03 \log (P+1)-0.11 \log (V+1) \\
F_{3,159}=211, \mathrm{r}^{2}=0.80, \mathrm{p}<0.001 \\
+\mathrm{NP}: G=-0.02+0.50 \log (R+1)- \\
0.39 \log (P+1)-0.03 \log (V+1) \\
F_{3,161}=210, \mathrm{r}^{2}=0.80, \mathrm{p}<0.001
\end{gathered}
$$

The Rho treatment produced a significantly greater rotifer growth rate than all other treatments under all nutrient conditions (with the exception of $R h o+\mathrm{F}$ in $-\mathrm{P}$, which produced the same) (Table 1, Fig 5). Rotifer growth rate followed the pattern $R h o+\mathrm{F}>$ Pry + Rho $>$ Pry under all nutrient conditions (Fig. 5). The starvation conditions produced lower growth rates than all other treatments except Pry (under all nutrient condi-

\begin{tabular}{|c|c|c|c|c|}
\hline \multicolumn{2}{|c|}{ Source of variation } & \multirow{2}{*}{$\frac{\mathrm{df}}{1}$} & \multirow{2}{*}{$\begin{array}{r}F \\
70\end{array}$} & \multirow{2}{*}{$\begin{array}{c}\mathrm{p} \\
<0.001\end{array}$} \\
\hline$+\mathrm{NP}$ & Pry / Pry + Rho & & & \\
\hline & Error & 72 & & \\
\hline & Total & 75 & & \\
\hline & Pry + Rho / Rho + F & 1 & 17.2 & $<0.001$ \\
\hline & Error & 57 & & \\
\hline & Total & 60 & & \\
\hline & Rho + F / Rho & 1 & 70.1 & $<0.001$ \\
\hline & Error & 72 & & \\
\hline & Total & 75 & & \\
\hline \multirow[t]{9}{*}{$-\mathrm{N}$} & Pry / Pry + Rho & 1 & 59.4 & $<0.001$ \\
\hline & Error & 71 & & \\
\hline & Total & 74 & & \\
\hline & Pry + Rho / Rho + F & 1 & 42.5 & $<0.001$ \\
\hline & Error & 56 & & \\
\hline & Total & 59 & & \\
\hline & Rho + F / Rho & 1 & 122.6 & $<0.001$ \\
\hline & Error & 72 & & \\
\hline & Total & 75 & & \\
\hline \multirow[t]{9}{*}{$-\mathrm{P}$} & Pry / Pry + Rho & 1 & 63 & $<0.001$ \\
\hline & Error & 71 & & \\
\hline & Total & 74 & & \\
\hline & Pry + Rho / Rho + F & 1 & 39.7 & $<0.001$ \\
\hline & Error & 57 & & \\
\hline & Total & 60 & & \\
\hline & Rho + F / Rho & 1 & 0.36 & 0.55 \\
\hline & Error & 72 & & \\
\hline & Total & 75 & & \\
\hline
\end{tabular}
tions) and Pry + Rho (in -N) (Fig. 5). These findings reveal that the abundance of $P$. parvum cells produced a greater toxic effect on rotifers than cell-free filtrates.

Table 1. Brachionus plicatilis. ANCOVA of the population growth rate with different treatments as factors and food concentration as covariate. Independent variables and covariate were log-transformed 

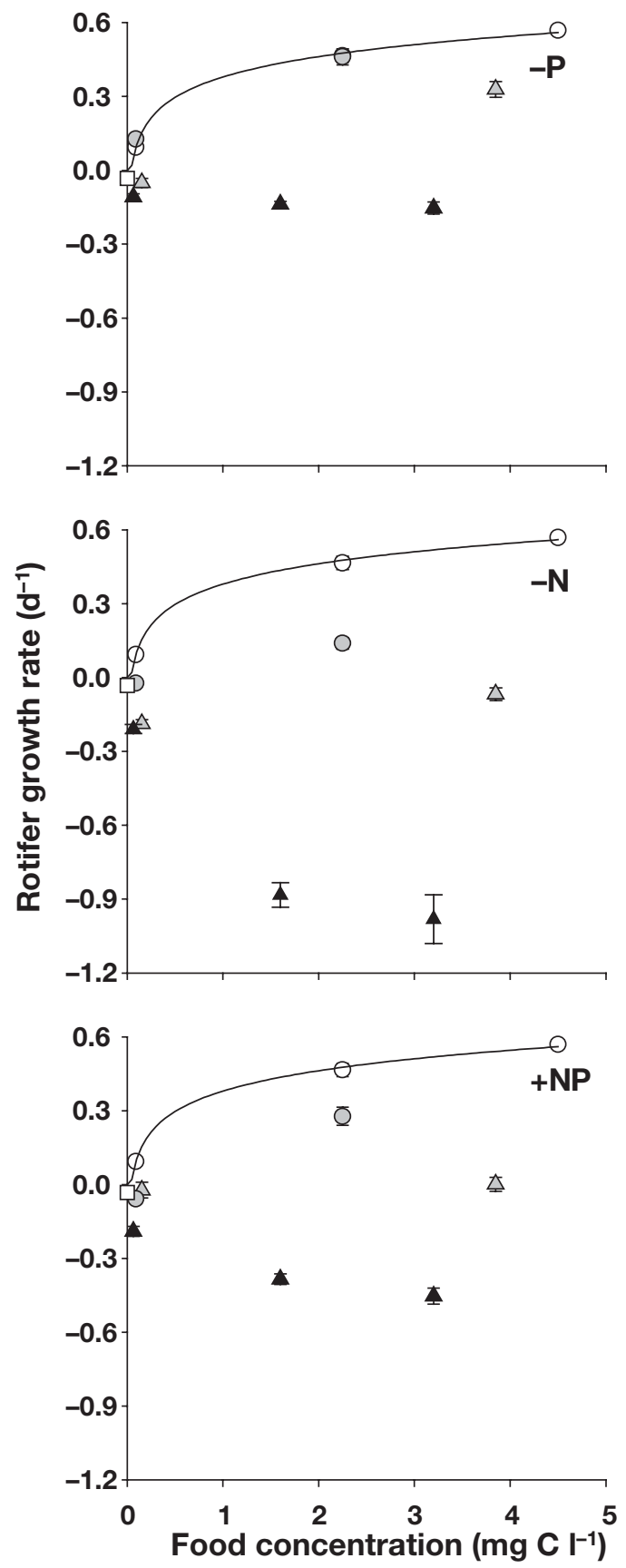

Fig. 5. Brachionus plicatilis. Relationship between total food concentration and population growth rate under the different treatments and nutrient conditions (mean $\pm \mathrm{SE}, \mathrm{n}=15$ ). $\square$ : starvation conditions; other symbols as in Fig. 4. The line represents the Rho control treatment

When comparing rotifer growth rate under the different nutrient conditions, the following pattern was observed: $-\mathrm{P}>+\mathrm{NP}>-\mathrm{N}$ (Table 2, Fig 5), indicating that the $-\mathrm{N}$ culture was most toxic for the rotifers, despite the fact that haemolytic activity was higher in -P (Fig. 2).
Table 2. Brachionus plicatilis. ANCOVA of the population growth rate with different nutrient conditions as factors and food concentration as covariate. Independent variables and covariate were log-transformed

\begin{tabular}{|c|c|c|c|c|}
\hline \multicolumn{2}{|c|}{ Source of variation } & \multirow{2}{*}{$\frac{\mathrm{df}}{2}$} & \multirow{2}{*}{$\begin{array}{c}F \\
81.4\end{array}$} & \multirow{2}{*}{$\begin{array}{c}\mathrm{p} \\
<0.001\end{array}$} \\
\hline Pry & $-\mathrm{P} /-\mathrm{N} /+\mathrm{NP}$ & & & \\
\hline & Error & 130 & & \\
\hline & Total & 134 & & \\
\hline \multirow[t]{3}{*}{ Pry + Rho } & $-\mathrm{P} /-\mathrm{N} /+\mathrm{NP}$ & 2 & 17.6 & $<0.001$ \\
\hline & Error & 85 & & \\
\hline & Total & 89 & & \\
\hline \multirow[t]{3}{*}{$R h o+\mathrm{F}$} & $-\mathrm{P} /-\mathrm{N} /+\mathrm{NP}$ & 2 & 24.7 & $<0.001$ \\
\hline & Error & 86 & & \\
\hline & Total & 90 & & \\
\hline
\end{tabular}

\section{DISCUSSION}

Fig. 6 summarises the effects of Prymnesium parvum on Rhodomonas salina and on the rotifers. The $P$. parvum cell-free filtrate had an effect on Brachionus plicatilis, although this was weak. B. plicatilis was also indirectly affected by $P$. parvum due to the negative effects of the toxic alga on their prey (Rhodomonas salina). However, the greatest negative effect of $P$. parvum on the rotifers was due to ingestion of the toxic cells (Fig. 5).

Previous studies have shown that excreted compounds of Prymnesium parvum are inhibitory to potential grazers, particularly ciliates (Fistarol et al. 2003), and even that $P$. parvum can kill and eat its predators

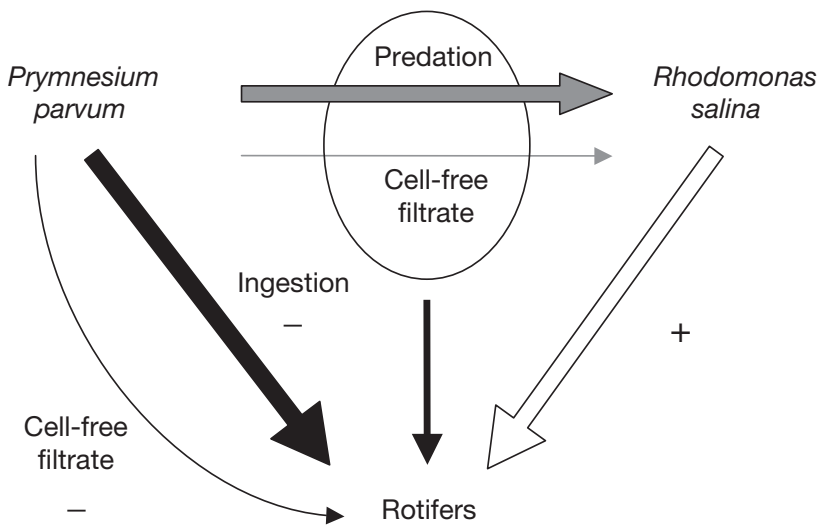

Fig. 6. Prymnesium parvum, Rhodomonas salina and Brachionus plicatilis. Negative $(-)$ and positive $(+)$ interactions. Black arrows indicate the effects of $P$. parvum on rotifers (solid line: direct effects; small black arrow: indirect effects), grey arrows the effects of $P$. parvum on $R$. salina and white arrow the effect of $R$. salina on rotifers. The thickness of the arrows indicates the importance of the interaction 
(Tillmann 2003). Toxic effects on protist grazers have also been observed with the ichthyotoxic Chrysochromulin polylepis (Tobiesen 1991). Excreted toxins produced by $P$. parvum also decrease egg production in the copepod Acartia clausi, which does not feed on P. parvum (Nejstgaard \& Solberg 1996). Similarly, in non-selective copepod species, such as Eurytemora affinis, mortality and egg production have been found to be more closely related to $P$. parvum cell density than to the number of ingested cells (Koski et al. 1999). Our results corroborate the hypothesis that compounds released by toxic species may function as a defence strategy by eliminating potential grazers. However, the negative effect produced by dissolved toxins on rotifers was not as important as the effect of $P$. parvum on their prey and the effect of toxic cell ingestion (Fig. 5).

Prymnesium parvum cell-free filtrate affected the growth rate of Rhodomonas salina, which is in agreement with other studies that have shown a negative effect of cell-free filtrates on phytoplankton species (Fistarol et al. 2003, Skovgaard \& Hansen 2003). Compounds released by $P$. parvum may allow them to outcompete other phytoplankton species and, therefore, the role of allelopathic compounds should be taken into account in competition studies between phytoplankton species (Fistarol et al. 2003). However, the presence of $P$. parvum cells had a greater effect on $R$. salina, which might be explained by predation of $P$. parvum on $R$. salina. These findings are similar to those obtained by Tillmann (2003), who found that mortality of Oxyrrhis marina cells, although affected by cell-free filtrates, was strongly increased when $P$. parvum cells were present. Therefore, our results support the hypothesis that toxins produced by $P$. parvum may cause immobilisation and/or cell lysis of potential phytoplankton competitors and even predators, but the most important effect is associated with its own predatory behaviour. However, the lower effect of cell-free filtrates could also be caused by toxins being lost from the water during filtration processes due to the formation of toxin aggregates (Tillmann 2003). Furthermore, if these toxins are especially labile, rapid degradation of toxins when toxic algal cells are absent would also influence the results obtained in our and other studies.

This effect of Prymnesium parvum on Rhodomonas salina indirectly affects rotifers, potential predators of $P$. parvum, because the reduced amount of food is more important than the effect of dissolved compounds excreted by $P$. parvum. This indirect effect could also be extrapolated to mesozooplankton species.

The ingestion rate of rotifers offered mixed prey was the same for both Prymnesium parvum and Rhodomonas salina, indicating a non-selective feeding behaviour towards the toxic cells. This suggests that toxins produced by $P$. parvum did not act as feeding deterrents to the rotifers. However, toxins produced by the haptophyte Chrysochromulina polylepis deter grazing by the dinoflagellate Oxyrrhis marina (John et al. 2002). The lack of feeding avoidance by the rotifer might be explained by the fact that the Brachionus plicatilis strain used in our study had not been exposed to $P$. parvum prior to our experiments. Feeding behaviour and resistance of the grazer to a specific toxic phytoplankton species have been shown to be affected by the exposure history of the grazer to that specific toxic alga (Colin \& Dam 2002). Another possible explanation is that toxicity in $P$. parvum may not have evolved in order to directly prevent grazing. In this sense, $P$. parvum toxins differ from feeding deterrence toxins (endotoxins) because they are excreted and have a direct effect on both predators and competitors (allelopathic). In contrast, endotoxins such as those that cause paralytic shellfish poisoning (PSP) need to be ingested by predators to exert their feeding deterrence effect (Dutz 1998, Teegarden 1999, Frangópulos et al. 2000, Guisande et al. 2002).

Prymnesium parvum was ingested in higher amounts when offered as the only prey than when offered with Rhodomonas salina. This may be explained by non-selective feeding behaviour. When $R$. salina is also present, the total ingestion rate of algae would be expected to be shared between both species. $R$. salina was ingested at a higher rate in $R h o+F$ treatments (except in $-\mathrm{P}$, where there was no toxic effect) than in Rho. This could be due to a higher grazing activity of rotifers stressed by toxins or even to an underestimation of the number of grazing rotifers (overestimating the number of dead rotifers).

It has been suggested that, prior to the onset of toxicity and bloom formation, some ciliate species may exert grazing pressure on Prymnesium parvum (Rosetta \& McManus 2003). Brachionus plicatilis fed on toxic cells; however, it is unlikely that grazing pressure on this harmful algal bloom species from rotifers contributes to the suppression or decline of $P$. parvum blooms, because rotifer mortality was very high when feeding on a monoculture of $P$. parvum. Although our results cannot be extrapolated to all microzooplankton species, we hypothesise that grazers are not able to control the proliferation of P. parvum.

In agreement with previous studies (Johansson \& Granéli 1999a,b, Legrand et al. 2001), haemolytic activity of Prymnesium parvum cells was higher under nutrient-limiting conditions, and higher under phosphorus than under nitrogen limitation. In contrast, $P$. parvum cultured under $+\mathrm{NP}$ conditions produced intermediate negative effects on rotifer growth compared to $-\mathrm{N}$ and $-\mathrm{P}$ conditions. This indicates that haemolytic activity is not a good indicator of the total potential negative effect of $P$. parvum on Brachionus 
plicatilis. Therefore, our findings reveal that $P$. parvum may produce deleterious compounds other than those detected with the haemolytic test.

Stepwise regressions also showed an important positive effect on rotifers due to the addition of Rhodomonas salina in the presence of Prymnesium parvum cells. This positive effect of non-toxic prey in the presence of $P$. parvum has already been observed for ciliates (Rosetta \& McManus 2003), dinoflagellates Oxyrrhis marina (Tillmann 2003) and copepods (Nejstgaard \& Solberg 1996). The negative effect of ingested $P$. parvum cells will be reduced when $R$. salina is added, because the total ingestion of $P$. parvum decreases. Moreover, toxins should be removed by binding to the membrane of $R$. salina cells, as suggested by Tillmann (2003) and Skovgaard \& Hansen (2003), decreasing toxin concentration in the water. However, in natural plankton communities, the death of most ciliates in the presence of both P. parvum cellfree filtrates and non-toxic prey has been reported (Fistarol et al. 2003).

In summary, our findings reveal that Rhodomonas salina may be primarily affected by predation of Prymnesium parvum cells and that Brachionus plicatilis may be primarily affected by ingestion of the toxic cells, the effects of compounds excreted into the water by $P$. parvum being secondary. Some studies have also found a strong negative influence of the presence of $P$. parvum cells on other predators, like the dinoflagellate Oxyrrhys marina (Tillmann 1998, 2003). On the other hand, other studies (Nejstgaard \& Solberg 1996, Fistarol et al. 2003, Rosetta \& McManus 2003, Skovgaard \& Hansen 2003) suggest that our conclusions should not be generalised to other phytoplankton competitors and predators.

From our results and previous studies, it is clear that Prymnesium parvum is unbeatable in biotic interactions (competition and predation) and its 'Achilles' heel' is probably in the abiotic factors that control its dominance in plankton communities.

Acknowledgements. We are very grateful to Tvärminne Zoological Station (University of Helsinki) for human and logistic support of this work. This research was supported by the European Commission through the project FATE 'Transfer and Fate of Harmful Algal Bloom (HAB) Toxins in European Marine Waters' (contract no EVK3-CT2000-00055), a project within the EUROHAB cluster, and the Spanish government through a FPU grant to AB. Culturing facilities at Tvärminne were partly funded by the Academy of Finland, grant 50723.

\section{LITERATURE CITED}

Aure J, Rey F (1992) Oceanographic conditions in the Sandsfjord system, western Norway, after a bloom of the toxic prymnesiophyte Prymnesium parvum Carter in August 1990. Sarsia 76:247-254
Colin SP, Dam HG (2002) Latitudinal differentiation in the effects of the toxic dinoflagellate Alexandrium spp. on the feeding and reproduction of populations of the copepod Acartia hudsonica. Harmful Algae 1:113-125

Dutz J (1998) Repression of fecundity in the neritic copepod Acartia clausi exposed to the toxic dinoflagellate Alexandrium lusitanicum: relationship between feeding and egg production. Mar Ecol Prog Ser 175:97-107

Edvarsen B, Paasche E (1998) Bloom dynamics and physiology of Prymnesium and Chrysochromulina. In: Anderson DM, Cembella AD, Hallegraef GM (eds) Physiological ecology of harmful algal blooms. NATO ASI Ser, Ser G 41:193-208

Fistarol GO, Legrand C, Granéli E (2003) Allelopathic effect of Prymnesium parvum on a natural plankton community. Mar Ecol Prog Ser 255:115-125

Frangópulos M, Guisande C, Maneiro I, Riveiro I, Franco JM (2000) Short-term and long-term effects of the toxic dinoflagellate Alexandrium minutum on the copepod Acartia clausi. Mar Ecol Prog Ser 203:161-169

Frost BW (1972) Effects of size and concentration of food particles on the feeding behavior of the marine planktonic copepod Calanus pacificus. Limnol Oceanogr 17:805-514

Granéli E, Johansson N (2003a) Increase in the production of allelopathic substances by Prymnesium parvum cells grown under N- or P-deficient conditions. Harmful Algae 2:135-145

Granéli E, Johansson N (2003b) Effects of the toxic haptophyte Prymnesium parvum on the survival and feeding of a ciliate: the influence of different nutrient conditions. Mar Ecol Prog Ser 254:49-56

Guillard RRL, Ryther JH (1962) Studies of marine planktonic diatoms. I. Cyclotella nana Hustdtand, Detonula confervacea Cleve. Can J Microbiol 8:229-239

Guisande C, Frangópolus M, Maneiro I, Vergara AR, Riveiro I (2002) Ecological advantages of toxin production by the dinoflagellate Alexandrium minutum under phosphorous limitation. Mar Ecol Prog Ser 225:169-176

Hällfors G, Hällfors S (1992) The Tvärminne collection of algal cultures. In: Pokki J (ed) Tvärminne studies, Vol 5. Yliopistopaino, Helsinki, p 15-17

Igarashi T, Aritake S, Yasumoto T (1998) Biological activities of Prymnesin-2 isolated from a red tide alga Prymnesium parvum. Nat Toxins 6:35-41

Johansson N, Granéli E (1999a) Influence of different nutrient conditions on cell density, chemical composition and toxicity of Prymnesium parvum (Haptophyta) in semicontinuous cultures. J Exp Mar Biol Ecol 239:243-258

Johansson N, Granéli E (1999b) Cell density, chemical composition and toxicity of Chrysochromulina polylepis (Haptophyta) in relation to different N:P supply ratios. Mar Biol 135:209-217

John U, Tillmann U, Medlin LK (2002) A comparative approach to study inhibition of grazing and lipid composition of a toxic and non-toxic clone of Chrysochromulina polylepis (Prymnesiophyceae). Harmful Algae 1:45-57

Koski M, Rosenberg M, Viitasalo M, Tanskanen S, Sjölund U (1999) Is Prymnesium patelliferum toxic for copepods? Grazing, egg production, and egestion of the calanoid copepod Eurytemora affinis in mixtures of 'good' and 'bad' food. ICES J Mar Sci 56:131-139

Larsen A, Bryant S (1998) Growth rate and toxicity of Prymnesium parvum and Prymnesium patelliferum (haptophyta) in response to changes in salinity, light and temperature. Sarsia 83:409-418

Legrand C, Johansson N, Johnsen G, Borshein KY, Granéli E (2001) Phagotrophy and toxicity variation in the mixo- 
trophic Prymnesium patelliferum. Limnol Oceanogr 46: 1208-1214

Lindholm T (1998) Algal phenomenon and algal problem. Åbo Akademi, Åbo (in Swedish)

Martín-Cereceda M, Novarino G, Young JR (2003) Grazing by Prymnesium parvum on small planktonic diatoms. Aquat Microb Ecol 33:191-199

Nejstgaard JC, Solberg PT (1996) Repression of copepod feeding and fecundity by the toxic haptophyte Prymnesium patelliferum. Sarsia 81:339-344

Nygaard K, Tobiesen A (1993) Bacterivory in algae: a survival strategy during nutrient limitation. Limnol Oceanogr 38: 273-279

Olsen Y, Reitan KI, Vadstein O (1993) Dependence of temperature on loss rates of rotifers, lipids, and w3 fatty acids in starved Brachionus plicatilis cultures. Hydrobiologia 255/ 256:13-20

Rosetta CH, McManus GB (2003) Feeding on two harmful algal blooms species, Prymnesium parvum and Prorocentrum minimum. Harmful Algae 2:109-126

Shilo M (1967) Formation and mode of action of algal toxins. Bacteriol Rev 31:180-193

Editorial responsibility: Fereidoun Rassoulzadegan, Villefranche-sur-Mer, France
Skovgaard A, Hansen PJ (2003) Food uptake in the harmful alga Prymnesium parvum mediated by excreted toxins. Limnol Oceanogr 48:1161-1166

Skovgaard A, Legrand C, Hansen PJ, Granéli E (2003) Effects of nutrient limitation on food uptake in the toxic haptophyte Prymnesium parvum. Aquat Microb Ecol 31: 259-265

Stolte W, Panosso R, Gisselsson LÅ, Granéli E (2002) Utilization efficiency of nitrogen associated with riverine organic carbon (>1 kDa) by two toxin-producing phytoplankton species. Aquat Microb Ecol 29:97-105

Teegarden GJ (1999) Copepod grazing selection and particle discrimination on the basis of PSP toxic content. Mar Ecol Prog Ser 181:163-176

Tillmann U (1998) Phagotrophy by a plastidic haptophyte, Prymnesium patelliferum. Aquat Microb Ecol 14:155-160

Tillmann U (2003) Kill and eat your predator: a winning strategy of the planktonic flagellate Prymnesium parvum. Aquat Microb Ecol 32:73-84

Tobiesen A (1991) Growth rates of Heterophrys marina (Heliozoa) on Chrysochromulina polylepis (Prymnesiophyceae). Ophelia 33:205-212

Submitted: June 14, 2004; Accepted: November 18, 2004 Proofs received from author(s): February 10, 2005 